\title{
Whole-cell bioreduction of aromatic $\alpha$-keto esters using Candida tenuis xylose reductase and Candida boidinii formate dehydrogenase co-expressed in Escherichia coli
} Regina Kratzer ${ }^{1,2}$, Matej Pukl ${ }^{1}$, Sigrid Egger ${ }^{1}$ and Bernd Nidetzky*1,2

Address: ${ }^{1}$ Institute of Biotechnology and Biochemical Engineering, Graz University of Technology (TUG), Petersgasse 12/1, A-8010 Graz, Austria and ${ }^{2}$ Research Centre Applied Biocatalysis, Petersgasse 14, A-8010 Graz, Austria

Email: Regina Kratzer - regina.kratzer@tugraz.at; Matej Pukl - matejpukl@gmail.com; Sigrid Egger - sigrid.egger@tugraz.at; Bernd Nidetzky* - bernd.nidetzky@tugraz.at

* Corresponding author

Published: 10 December 2008

Microbial Cell Factories 2008, 7:37 doi:10.1 I86/1475-2859-7-37
Received: 31 October 2008

Accepted: 10 December 2008

This article is available from: http://www.microbialcellfactories.com/content/7/l/37

(c) 2008 Kratzer et al; licensee BioMed Central Ltd.

This is an Open Access article distributed under the terms of the Creative Commons Attribution License (http://creativecommons.org/licenses/by/2.0), which permits unrestricted use, distribution, and reproduction in any medium, provided the original work is properly cited.

\begin{abstract}
Background: Whole cell-catalyzed biotransformation is a clear process option for the production of chiral alcohols via enantioselective reduction of precursor ketones. A wide variety of synthetically useful reductases are expressed heterologously in Escherichia coli to a high level of activity. Therefore, this microbe has become a prime system for carrying out whole-cell bioreductions at different scales. The limited capacity of central metabolic pathways in E. coli usually requires that reductase coenzyme in the form of NADPH or NADH be regenerated through a suitable oxidation reaction catalyzed by a second $\mathrm{NADP}^{+}$or $\mathrm{NAD}^{+}$dependent dehydrogenase that is co-expressed. Candida tenuis xylose reductase $(C t X R)$ was previously shown to promote NADH dependent reduction of aromatic $\alpha$-keto esters with high Prelog-type stereoselectivity. We describe here the development of a new whole-cell biocatalyst that is based on an $E$. coli strain coexpressing $C_{t} X \mathrm{R}$ and formate dehydrogenase from Candida boidinii (CbFDH). The bacterial system was evaluated for the synthesis of ethyl $R$-4-cyanomandelate under different process conditions and benchmarked against a previously described catalyst derived from Saccharomyces cerevisiae expressing $\mathrm{Ct}$ XR.
\end{abstract}

Results: Gene co-expression from a pETDuet-I vector yielded about 260 and 90 units of intracellular $C t X R$ and $C b F D H$ activity per gram of dry $E$. coli cell mass $\left(g_{C D W}\right)$. The maximum conversion rate $\left(r_{s}\right)$ for ethyl 4-cyanobenzoylformate by intact or polymyxin B sulphatepermeabilized cells was similar $\left(2 \mathrm{mmol} / \mathrm{g}_{\mathrm{CDw}} \mathrm{h}\right)$, suggesting that the activity of $\mathrm{CbFDH}$ was partly rate-limiting overall. Uncatalyzed ester hydrolysis in substrate as well as inactivation of $C_{t} \times R$ and $\mathrm{CbFDH}$ in the presence of the $\alpha$-keto ester constituted major restrictions to the yield of alcohol product. Using optimized reaction conditions ( $100 \mathrm{mM}$ substrate; $40 \mathrm{~g} \mathrm{CDW} / \mathrm{L}$ ), we obtained ethyl $R$-4-cyanomandelate with an enantiomeric excess (e.e.) of $97.2 \%$ in a yield of $82 \%$. By increasing the substrate concentration to $500 \mathrm{mM}$, the e.e. could be enhanced to $\cong 100 \%$, however, at the cost of a 3-fold decreased yield. A recombinant strain of $S$. cerevisiae converted $100 \mathrm{mM}$ substrate to 45 $\mathrm{mM}$ ethyl R-4-cyanomandelate with an e.e. of $\geq 99.9 \%$. Modifications to the recombinant $E$. coli (cell permeabilisation; addition of exogenous $\mathrm{NAD}^{+}$) and addition of a water immiscible solvent (e.g. hexane or I-butyl-3-methylimidazolium hexafluorophosphate) were not useful. To enhance the overall capacity for NADH regeneration in the system, we supplemented the original biocatalyst 
after permeabilisation with also permeabilised $E$. coli cells that expressed solely CbFDH (4I0 U/ $\left.g_{C D W}\right)$. The positive effect on yield $(18 \% \rightarrow 62 \%$; $100 \mathrm{mM}$ substrate) caused by a change in the ratio of FDH to XR activity from 2 to 20 was invalidated by a corresponding loss in product enantiomeric purity from $86 \%$ to only $71 \%$.

Conclusion: A whole-cell system based on $E$. coli co-expressing $C t X R$ and $C b F D H$ is a powerful and surprisingly robust biocatalyst for the synthesis of ethyl $R$-4-cyanomandelate in high optical purity and yield. A clear requirement for further optimization of the specific productivity of the biocatalyst is to remove the kinetic bottleneck of NADH regeneration through enhancement $(\geq$ I0-fold) of the intracellular level of FDH activity.

\section{Background}

Enzyme-catalyzed enantioselective reductions of ketones have become quite popular for the production of homochiral alcohols at industrial scale [1]. NAD(P)H-dependent reductases catalyze these transformations with exquisite chemo-, regio-, and stereoselectivities such that usually an optically pure product is obtained in high yield. Generally, the biocatalyst employed for ketone reduction can be a whole-cell system or a (partially) purified protein preparation [2-5]. The use of whole cells offers the important advantage of a simple, hence lowcost catalyst preparation. The synthetic reductase is oftentimes more stable within the cellular environment as compared to the isolated enzyme. Enzymatic reduction of ketones is usually performed in the presence of a substoichiometric amount of coenzyme (NADH or NADPH), implying that the catalytic reductant must be recycled during the conversion. Cells provide a basal capacity for coenzyme regeneration through the reduction of $\mathrm{NAD}^{+}$and $\mathrm{NADP}^{+}$in central metabolic pathways. The spatial organisation of the whole-cell system where enzymes and cofactors are encapsulated by the supramolecular structure of the cell membranes potentially improves the efficiency of coenzyme recycling as compared to homogeneous reactors employing "free-floating" biocatalytic components.

Considering the ability of Escherichia coli to over-express various synthetically useful ketoreductases to a high level of activity, this organism has become a prime choice for the development of whole-cell bioreduction catalysts. The capabilities of $E$. coli to provide internal cofactor regeneration are, however, oftentimes limiting overall [6-9]. Coexpression of another, $\mathrm{NAD}^{+}$or $\mathrm{NADP}^{+}$-dependent dehydrogenase is therefore used to couple the biosynthetic reduction of the target ketone with the oxidation of a suitable co-substrate. Currently, oxidation of glucose catalyzed by glucose dehydrogenase (GDH) is most often used for cofactor regeneration [2,6,9-14]. While the method effectively drives ketone reduction and can be flexibly applied to the recycling of NADH and NADPH, there is the clear disadvantage that the native glucose uptake system in E. coli involves coupled transport and phosphorylation. The resulting glucose 6-phosphate is not a substrate of GDH. To provide glucose efficiently for GDH-catalyzed oxidation, one must therefore make the cell membrane just sufficiently permeable for glucose (but not for coenzyme) or engineer the glucose uptake system [15-17]. Formation of gluconic acid as the ultimate oxidation product that is not further used in the reaction has a negative impact on the atom economy of the overall conversion. Moreover it requires that bioprocessing be performed under $\mathrm{pH}$ control [6,11,12,14,17]. Addition of concentrated base can lead to local peaks of high $\mathrm{pH}$ in imperfectly mixed bioreactors which in turn constitutes a strong factor of enzyme inactivation [18-20]. The use of GDH was further invalidated in this work because the ketoreductase employed for synthesis showed weak activity towards reduction of glucose into sorbitol [21].

Therefore, the ideal co-substrate should be readily taken up by the E. coli cell. It should not by itself or the product generated from it, inhibit or inactivate the synthetic ketoreductase. Oxidation of the co-substrate should be thermodynamically favoured, and the co-product should be easily removed from the reaction mixture. These demands are widely met by the conversion of formate into carbon dioxide catalyzed by formate dehydrogenase (FDH) [7, 17,22-26]. FDH enzymes from yeast and bacterial sources are typically specific for $\mathrm{NAD}^{+}$and can be used in a broad $\mathrm{pH}$ range ( $\mathrm{pH}$ 6.0-9.0; [27]). While many papers have been published on the use of isolated FDH for the regeneration of $\mathrm{NADH}$, particularly the enzyme from Candida boidinii ( $\mathrm{CbFDH}$ ), the development of corresponding whole-cell systems is not advancing as quickly. The relatively low specific activity of $\mathrm{CbFDH}(3$ $\mathrm{U} / \mathrm{mg}$, [28]) is considered a drawback for whole-cell applications of this enzyme.

We describe in this paper the construction of a novel whole-cell biocatalyst that was derived from E. coli BL21 (DE3) through co-expression of the genes encoding Candida tenuis xylose reductase (CtXR) and $C b F D H$. It was shown in previous work that CtXR promotes the reduction of aromatic $\alpha$-keto esters with useful efficiency and excellent stereoselectivity [29]. Here, the synthesis of ethyl $R$-4-cyanomandelate was employed to characterize and 
optimize the biocatalytic performance of the recombinant E. coli strain (Figure 1). The bacterial whole-cell system was compared with a recently developed strain of Saccharomyces cerevisiae that was designed for stereospecific reduction of aromatic $\alpha$-keto esters through overexpression of the gene encoding $C t \mathrm{XR}$.

\section{Results and discussion Co-expression of $\mathrm{CtXR}$ and $\mathrm{CbFDH}$ in E. coli}

The vector pETDuet-1-XR_FDH was constructed to enable co-expression of the genes encoding CtXR and $C b \mathrm{FDH}$. The specific activity of purified $\mathrm{CbFDH}$ (3 U/mg; [28]) is about 2-fold that of the purified CtXR on $10 \mathrm{mM}$ ethyl 4cyanobenzoylformate $(1.8 \mathrm{U} / \mathrm{mg})$. We placed the gene encoding $\mathrm{CbFDH}$ after the CtXR gene with the aim of specifically enhancing the overproduction of the formate dehydrogenase, as recommended by the supplier Novagen.

In a screening for conditions that are suitable for the simultaneous production of $\mathrm{CtXR}$ and $\mathrm{CbFDH}$ in $E$. coli BL21 (DE3), we compared low $(0.25 \mathrm{mM})$ and high (1.00 $\mathrm{mM}$ ) IPTG concentrations in combination with short (5 $\mathrm{h})$ and long $(20 \mathrm{~h})$ induction times. The specific activity of CtXR in the cell-free extract was not dependent on the IPTG concentration but enhanced from $0.58 \mathrm{U} / \mathrm{mg}$ to $0.91 \mathrm{U} / \mathrm{mg}$ by using the long induction phase. The specific activity of $C b$ FDH $(0.18 \mathrm{U} / \mathrm{mg})$ was insensitive to changes in any of the two cultivation parameters. By way of comparison, the specific activity of $\mathrm{CbFDH}$ in the cell extract of E. coli $\mathrm{FDH}$ was $1.4 \mathrm{U} / \mathrm{mg}$. The specific activity of $C t \mathrm{XR}$ in E. coli XR_FDH compares roughly to one of $0.49 \mathrm{U} / \mathrm{mg}$ that is obtained when using the expression vector $\mathrm{pBE}$ Act.1i in E. coli BL21 (DE3). The results also show that the activity ratio $C t \mathrm{XR} / \mathrm{Cb} \mathrm{FDH}$ in $E$. coli XR_FDH was $\sim 8$-fold higher than expected from the specific activities of the purified enzymes. Therefore, differential overproduction of $C t X R$ and $C b F D H$ to favour formation of the formate dehydrogenase did not occur with the expression construct used. We inspected E. coli XR_FDH under the light microscope and observed that a substantial amount of protein inclusion bodies was formed under induction conditions (data not shown). While intracellular precipitation could clearly account for losses of $\mathrm{CbFDH}$ activity, we considered the examination of folding factors for $\mathrm{CbFDH}$ in E. coli to be outside the scope of this paper. The level of $C b$ FDH expression using pETDuet-1-XR_FDH was comparable to that seen in previous work where $\mathrm{CbFDH}$ and an alcohol dehydrogenase were co-expressed in E. coli BL21 (DE3) from a pACYCDuet-1 vector [23]. Note that the arrangement of genes in the expression construct was similar in both studies.

Table 1 summarizes results of activity measurement for $E$. coli XR_FDH. To facilitate the comparison of different whole-cell catalysts, we normalized the results using $\mathrm{g}_{\mathrm{CDW}}$. The activity of CtXR (using xylose as the substrate) in E. coli XR_FDH was about 7 times the corresponding enzyme activity in $S$. cerevisiae XR2 $\mu$. The levels of the enzyme activities exploited in the regeneration of $\mathrm{NADH}$ were similar in E. coli XR_FDH and S. cerevisiae XR2 $\mu$ (alcohol dehydrogenase; $\mathrm{ADH}$ ). With the assay used [30], the level of $\mathrm{NAD}^{+}$-dependent aldehyde dehydrogenase (AlDH) activity in $S$. cerevisiae XR2 $\mu$ was below detection limit (< $\left.0.2 \mathrm{U} / \mathrm{g}_{\mathrm{CDW}}\right)$. The wild-type strain of $S$. cerevisiae as well as E. coli FDH shows no ethyl 4-cyanobenzoylformate reductase activity in the absence of CtXR overexpression.

\section{Whole cell-catalyzed reduction of ethyl 4- cyanobenzoylformate}

We compared the initial rates of substrate reduction $\left(r_{\mathrm{S}}\right)$ by E. coli XR_FDH, $S$. cerevisiae XR $2 \mu$, and the wild-type strain of $S$. cerevisiae. A low substrate concentration of 10 $\mathrm{mM}$ was chosen to decrease toxic effects of ethyl 4cyanobenzoylformate on the cells (see later). Yeast bioreduction experiments were carried out under anaerobic

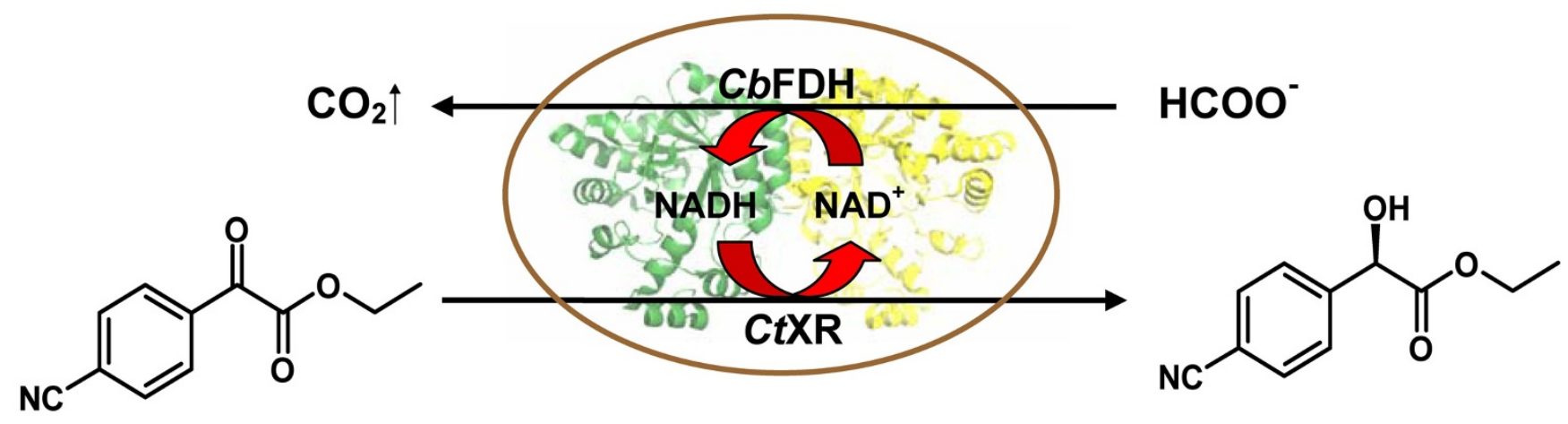

\section{Figure I}

Whole-cell biocatalytic reduction of ethyl 4-cyanobenzoylformate using a recombinant strain of $E$. coli coexpressing Candida tenuis xylose reductase $(C t X R)$ and Candida boidinii formate dehydrogenase (CbFDH). 
Table I: Biosynthetic and NADH regenerating enzyme activities in different strains of $E$. coli and S. cerevisiae

\begin{tabular}{lll}
\hline strain & XR activity $\left[\mathrm{U} / \mathrm{g}_{\mathrm{CDW}}\right]^{\prime} \mathrm{NADH}$-dependent & dehydrogenase activity $\left[\mathrm{U} / \mathrm{g}_{\mathrm{CDW}}\right]^{\prime} \mathrm{NADH}^{+}$-dependent \\
\hline E. coli XR_FDH & 256 & $85(\mathrm{FDH})$ \\
\hline E. coli FDH & 0 & $408(\mathrm{FDH})$ \\
\hline S. cerevisiae XR2 $\mu$ & 35 & $174(\mathrm{ADH})$ \\
\hline S. cerevisiae wild-type & 0 & $\mathrm{I} / 2(\mathrm{ADH})$ \\
\hline
\end{tabular}

'Standard errors $\leq 15 \%$.

conditions in the presence of ethanol as co-substrate to promote $\mathrm{ADH}$-catalyzed regeneration of $\mathrm{NADH}$ while suppressing at the same time routes that could recycle NADPH. Kratzer et al. [31] have recently shown that reduction of aromatic $\alpha$-keto esters by $S$. cerevisiae XR2 $\mu$ proceeded under these conditions with the near perfect enantioselectivity of isolated CtXR in analogous conversions. Initial rates $\left(r_{\mathrm{S}}\right)$ were calculated from linear time courses of substrate conversion in the first $\cong 1 \mathrm{~h}$ of reaction, and results are summarized in Table 2. $r_{\mathrm{S}}$-Values for the bacterial strain and $S$. cerevisiae XR2 $\mu$ were similar and surpassed that for the wild-type yeast by a factor of 10 . The comparison of data in Tables 1 and 2 reveals that the observed pattern of $r_{\mathrm{S}}$ values is not reflected clearly in the activity levels for the biosynthetic and NADH-regenerating enzymes that are present in the different cells. However, we must consider that $r_{\mathrm{S}}$ is a kinetically complex parameter (Figure 1) that is also prone to mass transfer effects.
The e.e. of the alcohol product obtained by using $E$. coli XR_FDH was reasonable but not as good as in bioreductions with $S$. cerevisiae XR2 $\mu$ or the isolated CtXR (Table 2, $[29,31])$. This result and evidence presented later indicate that in contrast to the widely held notion $[6,7]$ the effect of the E. coli reductase background must not generally be neglected during development of a whole-cell catalyst for reduction of ketones $[6,9,14]$. The stereochemical outcome of the conversion of ethyl 4-cyanobenzoylformate by E. coli XR_FDH, however, presented a clear improvement in terms of selectivity as compared to reduction of the same substrate by the wild-type strain of S. cerevisiae.

Table 2 also shows the effect of varied substrate and cell concentrations on $r_{\mathrm{S}}$ for $E$. coli XR_FDH. At a given concentration of ethyl 4-cyanobenzoylformate, $r_{\mathrm{S}}$ was largely independent of the cell concentration used in the experiment. $r_{\mathrm{S}}$ was doubled in response to an increase in substrate concentration from $10 \mathrm{mM}$ to $100 \mathrm{mM}$. However, as the solubility of ethyl 4-cyanobenzoylformate was only around $10 \mathrm{mM}$ under the conditions used, the availability

Table 2: Initial rates and ee-values of ethyl 4-cyanobenzoylformate reduction by different whole-cell biocatalysts.

\begin{tabular}{llll}
\hline strain & cell dry weight $[\mathrm{g} / \mathrm{L}]$ & substrate conc. & initial rate $\left[\mathrm{mmol}^{\prime} \mathrm{g} \mathrm{h}\right] / / \mathrm{ee}{ }^{2}[\%]$ \\
\hline E. coli XR_FDH & 5 & 10 & $0.60 / 97.0 R$ \\
\hline E. coli XR_FDH & 5 & 100 & $1.12 / 99.0 R$ \\
\hline E. coli XR_FDH & 20 & 100 & $1.39 / 99.3 R$ \\
\hline E. coli XR_FDH & 40 & 100 & $1.19 / 98.6 R$ \\
\hline E. coli XR_FDH & 40 & 500 & $1.94 / 99.9 R$ \\
\hline S. cerevisiae XR2 $\mu^{3}$ & 5 & 10 & $0.26 / \geq 99.9 R$ \\
\hline S. cerevisiae XR2 $\mu^{3}$ & 40 & 100 & $1.03 / \geq 99.9 R$ \\
\hline S. cerevisiae wild-type ${ }^{3}$ & 5 & 10 & $0.06 / 80.4 R$
\end{tabular}

'Determined from the time course of substrate conversion between 0 and $\leq 1.4 \mathrm{~h}$ reaction time; standard errors $\leq 20 \%$. ${ }^{2}$ The detection limit of ethyl 4-cyanomandelate is below $0.01 \mathrm{mM}$. ${ }^{3}$ Anaerobic reaction conditions where $\left[\mathrm{O}_{2}\right]<15 \mu \mathrm{M}$; ethanol was used as co-substrate. 
of substrate at higher concentrations of the keto ester was not clear. The 1.6-fold enhancement in $r_{\mathrm{S}}$ resulting from an increase in substrate concentration from $100 \mathrm{mM}$ to $500 \mathrm{mM}$ is interesting as it seems to imply uptake of ethyl 4-cyanobenzoylformate by the cells directly from the organic phase. The concentration of substrate dissolved in the aqueous phase will be the same irrespective of the total substrate concentration being $100 \mathrm{mM}$ or $500 \mathrm{mM}$. Another important implication of Table 2 is that e.e. increased as the substrate concentration was raised. The level of substrate that was optimal with respect to maximizing the e.e. was dependent on the cell concentration used. The results suggest that the E. coli reductase background which is responsible for the lowering of the optical purity of product was inhibited by high substrate concentrations.
Figure 2 shows the full time courses of substrate conversion by E. coli XR_FDH under the conditions that were used for determination of initial rates in Table 2. In terms of product yield based on substrate used in the overall reaction, the choice of a cell concentration of $40 \mathrm{~g}_{\mathrm{cdw}} / \mathrm{L}$ and a substrate concentration of $100 \mathrm{mM}$ was best and used during further optimization of the whole-cell biotransformation. However, the maximum yield obtained in Figure 2 was significantly below 100\%, making it also necessary to examine the factors that limit conversion of ethyl 4-cyanobenzoylformate into product. Note that when using $S$. cerevisiae XR2 $\mu\left(40 \mathrm{~g}_{\mathrm{CDW}} / \mathrm{L}\right)$, the yield from $100 \mathrm{mM}$ ethyl 4-cyanobenzoylformate was $45 \%$ (data not shown).

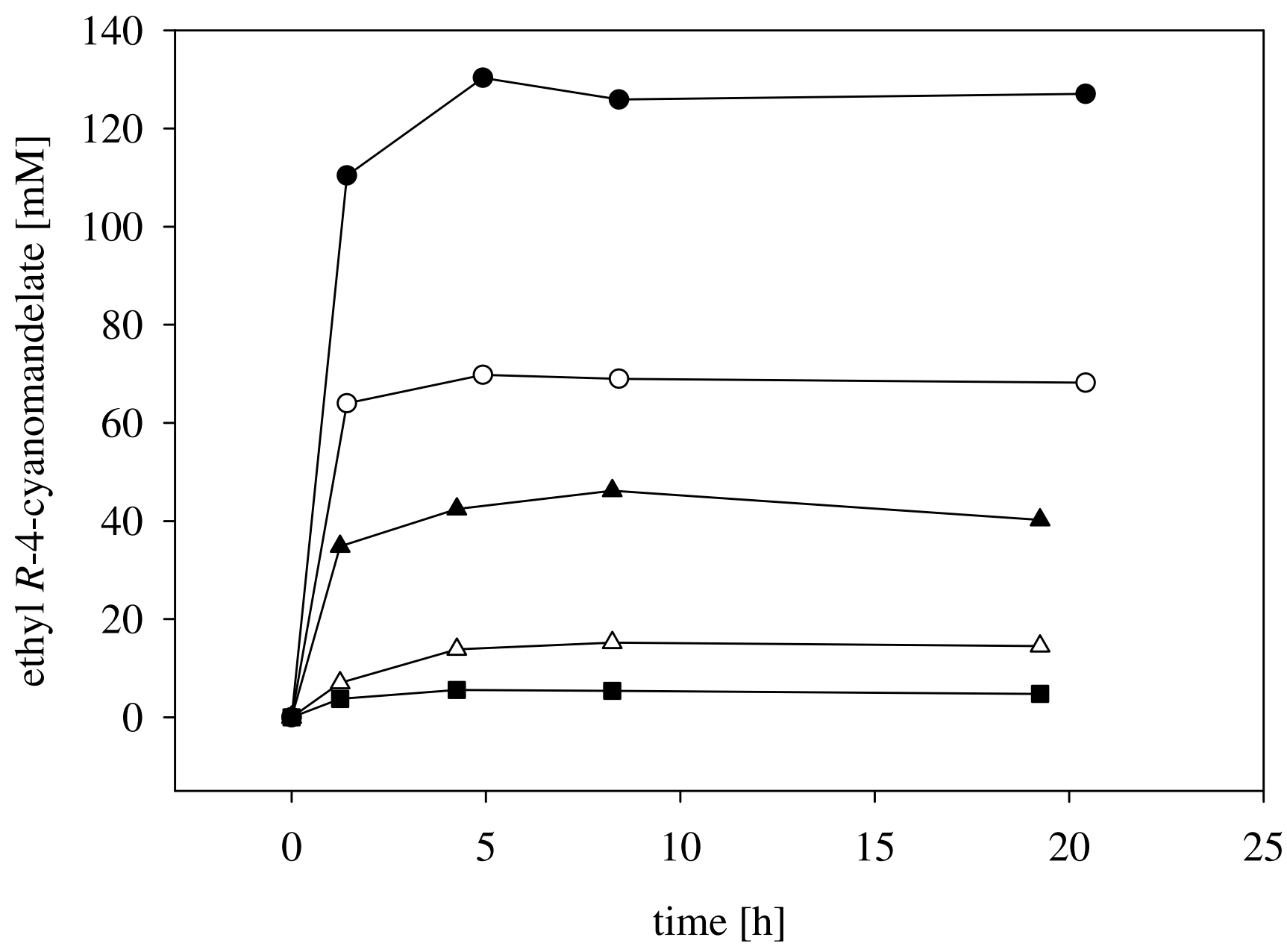

Figure 2

Whole cell-catalyzed reduction of ethyl 4-cyanobenzoylformate by $\mathbf{E}$. coli XR_FDH. The analytical yield is given and expressed as concentration of ethyl 4-cyanomandelate formed from the initial substrate concentration. Conditions are indicated by symbols: $[$ substrate] $=500 \mathrm{mM}$, [cells] = $40 \mathrm{~g} \mathrm{CDW} / \mathrm{L} ; \bigcirc$ [substrate] $=100 \mathrm{mM}$, [cells] $=40 \mathrm{~g} \mathrm{CDW} / \mathrm{L} ; \boldsymbol{\Delta}$ [substrate] = $100 \mathrm{mM}$, [cells] = $20 \mathrm{~g}$ CDW $/ \mathrm{L} ; \Delta$ [substrate] = $100 \mathrm{mM}$, [cells] = $5 \mathrm{~g} \mathrm{CDW} / \mathrm{L} ; \mathbf{\square}$ [substrate] $=10 \mathrm{mM}$, [cells] $=5 \mathrm{gCDW} / \mathrm{L}$. 


\section{Limitations in whole-cell reductions of ethyl 4- cyanobenzoylformate by E. coli XR_FDH and S. cerevisiae $X R 2 \mu$}

Time courses of reduction of ethyl 4-cyanobenzoylformate were characterized by a sharp decrease in the conversion rate which irrespective of the amount of product already formed under the different experimental conditions, occurred at approximately the same time during the initial phase of the transformation (Figure 2). Chemical degradation of substrate and/or product and deactivation of XR and/or enzymes involved in coenzyme regeneration are factors that could account for the observed slowing down of the reaction and hence limit the final yield of alcohol product (Figure 3). We incubated $100 \mathrm{mM}$ ethyl 4-cyanobenzoylformate identically as in Figure 2 but in the absence of biomass as a control and measured sponta- neous decomposition of the substrate [32], which is most probably due to hydrolysis (Figure 3). Ethyl 4-cyanobenzoylformate was quite unstable, its calculated half-life time being only about $1.4 \mathrm{~h}$. No detectable degradation of the product ethyl 4-cyanomandelate took place under the same conditions during a 6 -h long incubation (data not shown). The presence of the $\alpha$-keto ester substrate (100 $\mathrm{mM}$ ) had a strong negative impact on the stabilities of XR and FDH in E. coli XR_FDH cells, as shown in Figure 3. The calculated half-life time of XR was $1.4 \mathrm{~h}$, that of FDH was $1.5 \mathrm{~h}$. In the absence of substrate, the two enzymes were fully stable over the period of 6 hs [28]. Therefore, these results imply that reduction of ethyl 4-cyanobenzoylformate is critically limited by substrate as well as biocatalyst stability. In order to obtain high product yield, it would thus be necessary that $r_{\mathrm{S}}$ is much larger throughout

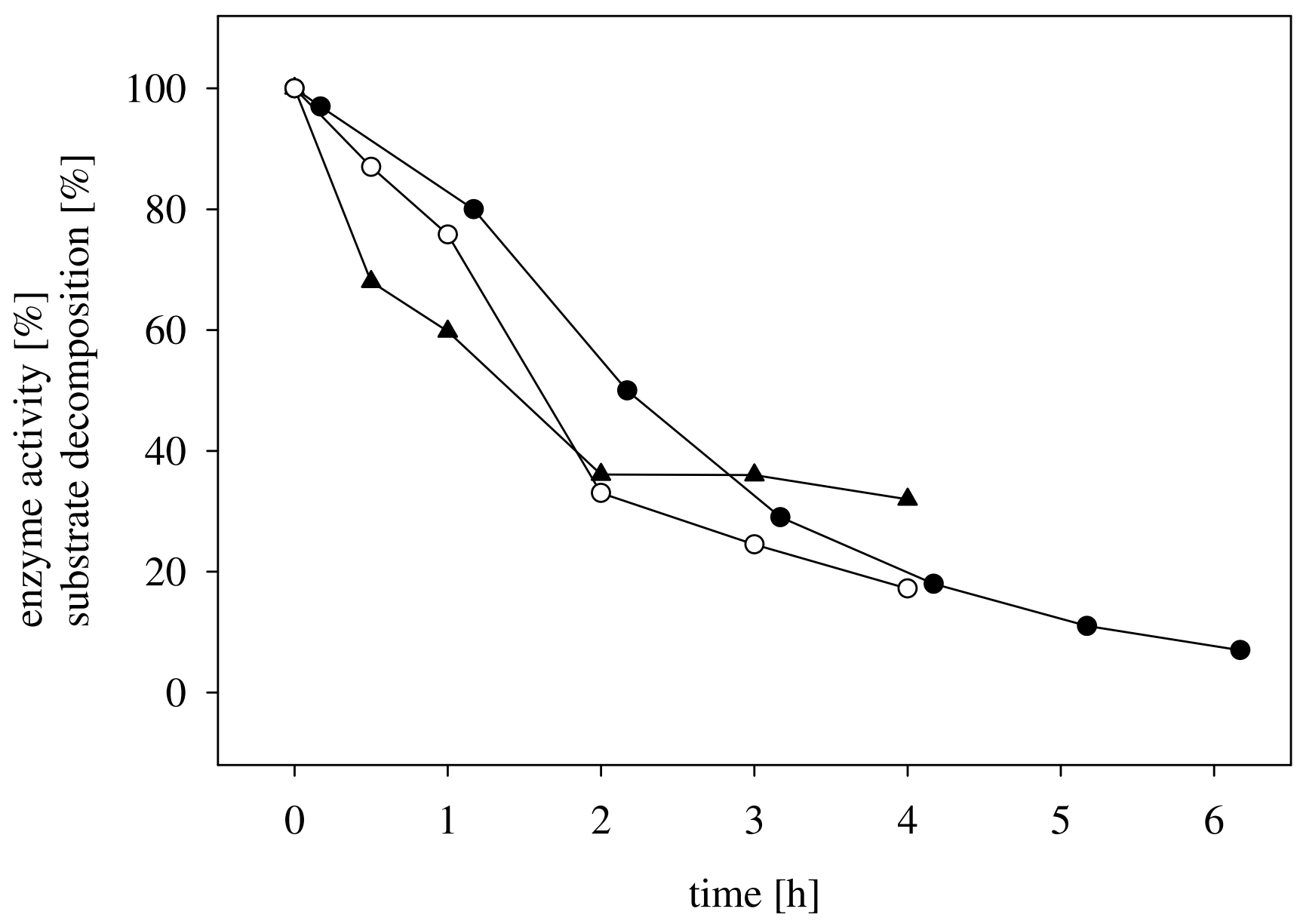

Figure 3

Inactivation of enzymes and spontaneous decomposition of substrate are limiting factors during whole cellcatalyzed reduction of ethyl 4-cyanobenzoylformate by $\boldsymbol{E}$. coli XR_FDH. Inactivation: $E$. coli XR_FDH (40 gCDW/L) was incubated in the presence of $100 \mathrm{mM}$ ethyl 4-cyanobenzoylformate and at the indicated times, enzyme activities were measured after cell disruption using B-Per ( $O$ CtXR activity, $\mathbf{\Delta}$ CbFDH activity). Substrate decomposition: $100 \mathrm{mM}$ ethyl 4cyanobenzoylformate was incubated in potassium phosphate buffer $50 \mathrm{mM}$, pH 7.5, lacking cells, and the concentration of the compound was measured by HPLC in samples taken at the indicated times (0). 
than the decomposition rate of the substrate. Likewise, unless stabilized against inactivation by the organic substrate, cells cannot be re-used for multiple rounds of batchwise substrate conversion. Feeding the substrate at a moderately toxic concentration [33] and the use of less toxic organic co-solvents (see later) might be relevant process options with which to enhance both substrate utilization and the total turnover number of the enzymes. The development of a fed-batch process was beyond the scope of this paper.

The half-life time of XR in $S$. cerevisiae XR2 $\mu$ was $2.7 \mathrm{~h}, \mathrm{a} \cong$ 2-fold increase in enzyme stability as compared to the $E$. coli XR_FDH system. According to literature [34] baker's yeast is more resistant than E. coli to the denaturing effects of organic compounds, irrespective of whether they are soluble or present as a second liquid phase. Therefore, this could explain the observed stabilisation of XR. Note that a soluble preparation of XR has a half-life time of $3.7 \mathrm{~min}$ when exposed to $100 \mathrm{mM}$ ethyl 4-cyanobenzoylformate, indicating that the whole-cell environment of S. cerevisiae or $E$. coli generally provides significant protection to the enzyme. However, with a half-life of only $0.8 \mathrm{~h}$, the stability of ADH appeared to determine overall lifetime of the yeast whole-cell catalyst under the conditions used for $\alpha$ keto ester reduction.

\section{Effect of organic co-solvents on ethyl 4- cyanobenzoylformate reduction}

We considered that a water-immiscible organic co-solvent could, by lowering the substrate concentration in the aqueous phase which contains the whole-cell catalyst, improve the stability of all critical components in the reaction system for ethyl 4-cyanobenzoylformate reduction. A widely held notion is that the toxicity of organic solvents on whole cells decreases as their $\log P$ value increases. We therefore selected three common solvents covering a $\log P$ range from 0.68 to 3.5 (ethyl acetate 0.68 ; butyl acetate 1.7; hexane 3.5) and one ionic liquid (1-butyl-3-methylimidazolium hexafluorophosphate $\left.\left(\mathrm{BMIMPF}_{6}\right)\right)$. The $\mathrm{BMIMPF}_{6}$ co-solvent was chosen considering the report of Bräutigam et al. [22] where this ionic liquid was described as biocompatible and not damaging to cells. Taking into account the relevant literature (e.g. $[22,35,36])$, it was unexpected that both E. coli XR_FDH (Table 3) and S. cerevisiae XR2 $\mu$ (data not shown) displayed a significantly poorer biocatalytic performance in the presence of co-solvent than in the absence thereof. By way of comparison, the use of $\mathrm{BMIMPF}_{6}$ caused $\cong 13$-fold enhancement of space-time-yield in the reductive conversion of a $\beta$-keto ester catalyzed by whole cells of $E$. coli co-expressing a ketoreductase and bacterial FDH [22]. Therefore, these findings provide a note of caution concerning generalisation of the use of organic co-solvents for whole cell-catalyzed reduction of ketones. They also emphasize that despite the clear focus on E. coli and $S$. cerevisiae in the development of whole-cell biocatalysts [13,37,38], there remains the requirement for case-specific optimization of reaction conditions by medium engineering.

\section{Effect of cell permeabilization and externally added NAD on ethyl 4-cyanobenzoylformate reduction}

Evidence from previous studies of ketone reduction by whole-cell biocatalysts suggests that $r_{\mathrm{S}}$ can in certain cases be enhanced by making the cell wall more easily permeable for low-molecular weight compounds such as substrates, products and if applied, external NAD $(P)$ cofactors [10,39-43]. From the various methods reported for permeabilization of Gram-negative bacteria [44], we selected treatment with the antibiotic polymyxin B sulphate because of its mainly locally disruptive effect on cell wall integrity. Polymyxin B sulphate binds to the lipid A portion of bacterial lipopolysaccharides and induces pore formation in the membrane [45]. Data in Table 3 shows that the chosen permeabilization did not affect the performance of E. coli XR_FDH in the conversion of ethyl 4cyanobenzoylformate. Likewise, the addition of $\mathrm{NAD}^{+}$ (see $[6,13,23])$ to intact or polymyxin B sulphate-treated cells of E. coli XR_FDH did not enhance the product yield in reactions performed in aqueous buffer. Under conditions where an organic co-solvent or $\mathrm{BMIMPF}_{6}$ was present, however, the yield was improved up to 9-fold as result of supplementation of the medium with external $\mathrm{NAD}^{+}$. Summarizing, the highest yield $(\cong 80 \%)$ of ethyl $R$ 4-cyanomandelate from $100 \mathrm{mM}$ substrate was obtained when using aqueous buffer lacking co-solvents and other additives. Note that conversion of the $\alpha$-keto ester via enzymatic reduction and the competing route of chemical decomposition was complete in all experiments, implying that $\geq 20 \%$ of the used substrate was lost to non-enzymatic transformations. The absence of a rate-enhancing effect of external $\mathrm{NAD}^{+}$may be explicable on account of the total intracellular concentration of $\operatorname{NAD}(\mathrm{H})$ which is around $1 \mathrm{mM}$ [46]. Considering the $K_{\mathrm{m}}$ values of CtXR [47] and $\mathrm{CbFDH}$ [23] for NADH and $\mathrm{NAD}^{+}$which are 38 $\mu \mathrm{M}$ and $90 \mu \mathrm{M}$, respectively, it seems probable that the levels of reduced and oxidized coenzyme in $E$. coli are high enough to saturate the coupled enzyme system. Permeabilization of $S$. cerevisiae XR2 $\mu$ was not pursued.

\section{Evidence for limitation of $\mathbf{r}_{S}$ by the activity of FDH}

E. coli XR_FDH showed a XR to FDH activity ratio of $3: 1$, which may not be optimal for biocatalytic synthesis. The level of FDH activity in E. coli FDH was 5 times that of $E$. coli XR_FDH (Table 1). We therefore used E. coli FDH to complement the possible deficit of E. coli XR_FDH with respect to FDH activity. Experiments were performed at a constant XR activity of $1.4 \mathrm{U} / \mathrm{mL}$ (equivalent to $5 \mathrm{~g}_{\mathrm{CDW}} / \mathrm{L}$ E. coli XR_FDH) and the activity of FDH was varied at levels of 3, 9 and $27 \mathrm{U} / \mathrm{mL}$. Both E. coli strains were permea- 
Table 3: Effect of additives and co-solvents on yield and enantiomeric excess of whole-cell bioreduction of ethyl 4cyanobenzoylformate catalyzed by $E$. coli XR_FDH.

\begin{tabular}{|c|c|c|c|}
\hline substrate conc. [mM] & org. co-solvent ${ }^{\mathrm{I}}$ & additive $^{2,3}$ & yield $[\mathrm{mM}]^{4} / \mathrm{ee}[\%]^{5}$ \\
\hline 100 & & & $82 / 97.2 R$ \\
\hline 100 & & $\mathrm{NAD}^{+}$ & $85 / 97.1 R$ \\
\hline 100 & & polymyxin B & $75 / 97.0 R$ \\
\hline 100 & & $\mathrm{NAD}^{+}$, polymyxin B & $77 / 97.2 R$ \\
\hline 100 & ethyl acetate & & $1 />99.9 R$ \\
\hline 100 & ethyl acetate & $\mathrm{NAD}^{+}$ & $9 />99.9 R$ \\
\hline 100 & hexane & & $3 />99.9 R$ \\
\hline 100 & hexane & $\mathrm{NAD}^{+}$ & $7 />99.9 R$ \\
\hline 500 & & & |34/> $99.9 R$ \\
\hline 500 & & $\mathrm{NAD}^{+}$ & $136 />99.9 R$ \\
\hline 500 & & polymyxin B & $125 />99.9 R$ \\
\hline 500 & & $\mathrm{NAD}^{+}$, polymyxin B & $\mid 26 />99.9 R$ \\
\hline 500 & butyl acetate & & $9 />99.9 R$ \\
\hline 500 & butyl acetate & $\mathrm{NAD}^{+}$ & $35 />99.9 R$ \\
\hline 500 & $\mathrm{BMIMPF}_{6}$ & & $74 />99.9 R$ \\
\hline 500 & BMIMPF $_{6}$ & $\mathrm{NAD}^{+}$ & $108 />99.9 R$ \\
\hline
\end{tabular}

Conditions: $40 \mathrm{~g}$ CDW/L; $8.5 \mathrm{~h}$ reaction time. ${ }^{1}$ Co-solvents were added in I:I volume ratio. ${ }^{2}\left[\mathrm{NAD}^{+}\right.$] $=490 \mu \mathrm{M} .{ }^{3}$ [polymyxin B sulphate] $=\mid 44 \mu \mathrm{M}$. ${ }^{4}$ Standard errors $\leq 15 \% .{ }^{5}$ Detection limit of ethyl 4-cyanomandelate is below $0.01 \mathrm{mM}$.

bilized using polymyxin B sulphate, and external NAD ${ }^{+}$ was also added. Results are summarized in Table 4. They show that product yield increased markedly ( $\cong 3.5$-fold) in response to a 10-fold increase in FDH activity, demonstrating that $r_{\mathrm{S}}$ of $E$. coli XR_FDH is limited by NADH regeneration capacity. The presence of external $\mathrm{NAD}^{+} \mathrm{did}$ not stimulate $r_{\mathrm{S}}$ in the two-strain system, indicating that it is availability of NADH, however not that of total coenzyme that restricts the synthesis rate. Using a comparable system where one E. coli strain expressed the synthetic ketoreductase and another GDH for regeneration of NADPH, Xu et al. [9] made the observation that the cellular pools of coenzyme are sufficient to promote ketone reduction. Table 4 reveals that the optical purity of product decreased significantly in response to an increase in the total biomass concentration that was necessary to raise the level of $\mathrm{FDH}$, relative to that of $\mathrm{XR}$, in the reaction. The result provides a note of caution regarding the role of the
E. coli ketoreductase background in the overall conversion of the ketone substrate (see also, $[6,9,14]$.

\section{Conclusion}

A whole-cell system based on E. coli co-expressing CtXR and $\mathrm{CbFDH}$ is a powerful biocatalyst for the synthesis of ethyl $R$-4-cyanomandelate in high optical purity and useful yield. The performance of the novel E. coli strain in the conversion of $100 \mathrm{mM} \alpha$-keto ester substrate surpassed that of a yeast strain previously developed for chiral alcohol production using CtXR-catalyzed reduction [31]. Ethyl 4-cyanobenzoylformate was highly "toxic" to the bacterial and yeast biocatalysts, causing rapid inactivation of $C t \mathrm{XR}$ and $\mathrm{CbFDH}$ in E. coli and likewise, $\mathrm{CtXR}$ and $\mathrm{ADH}$ in $S$. cerevisiae. In the absence of a suitable co-solvent that alleviates the toxic effect, a fed-batch transformation might be the most promising process option for each strain. A clear requirement for further optimization of the 
Table 4: Effect of varied activity ratio for $C t X R$ and $C b F D H$ during whole cell-catalyzed reduction of $100 \mathrm{mM}$ ethyl 4cyanobenzoylformate by a suitable mixture of E. coli XR_FDH and E. coli FDH.

\begin{tabular}{|c|c|c|c|}
\hline substrate conc. [mM] & $\mathrm{XR}: \mathrm{FDH}$ & additive $^{1,2}$ & yield $[\mathrm{mM}]^{3 / e e}[\%]^{4}$ \\
\hline 100 & $1: 2$ & polymyxin B & $|8 / 86| R$. \\
\hline 100 & $1: 6$ & polymyxin B & $36 / 74.6 R$ \\
\hline 100 & $1: 20$ & polymyxin B & $62 / 71.3 R$ \\
\hline 100 & $1: 2$ & $\mathrm{NAD}^{+}$, polymyxin B & $23 / 66.8 R$ \\
\hline 100 & $1: 6$ & $\mathrm{NAD}^{+}$, polymyxin B & $36 / 64.7 R$ \\
\hline 100 & $1: 20$ & $\mathrm{NAD}^{+}$, polymyxin B & $64 / 7 I .2 R$ \\
\hline 500 & $1: 2$ & polymyxin B & $25 / \geq 99.9 R$ \\
\hline 500 & $1: 6$ & polymyxin B & $39 / 84.6 R$ \\
\hline 500 & $1: 20$ & polymyxin B & 88/73.7 R \\
\hline 500 & $1: 2$ & $\mathrm{NAD}^{+}$, polymyxin B & $29 / \geq 99.9 R$ \\
\hline 500 & $1: 6$ & $\mathrm{NAD}^{+}$, polymyxin B & $42 / 85.1 R$ \\
\hline 500 & $1: 20$ & $\mathrm{NAD}^{+}$, polymyxin B & $90 / 75.5 R$ \\
\hline
\end{tabular}

The activity of $C t X R$ was kept constant at $1.4 \mathrm{U} / \mathrm{mL}$ throughout.

${ }^{1}\left[\mathrm{NAD}^{+}\right]=490 \mu \mathrm{M},{ }^{2}$ [polymyxin B sulphate] $=144 \mu \mathrm{M} ;{ }^{3}$ Standard errors $\leq 15 \%$. ${ }^{4}$ Detection limit of ethyl 4-cyanomandelate is below $0.01 \mathrm{mM}$.

specific productivity of the E. coli biocatalyst is to remove the kinetic bottleneck of NADH regeneration through enhancement ( $\geq 10$-fold) of the intracellular level of FDH activity. Because yeast FDHs in their wild-type forms show rather low specific activities $[28,48])$, powerful expression systems or more active variants of the enzyme [48] should be employed $[7,17,22,24]$.

\section{Methods}

\section{Chemicals and strains}

Ethyl 4-cyanobenzoylformate was purchased at SigmaAldrich (Vienna, Austria). Racemic ethyl 4-cyanomandelate was from Synthon Chemicals GmbH \& Co. KG (Wolfen, Germany). NADH (sodium salt; $\geq 98 \%$ pure), $\mathrm{NAD}^{+}$(free acid; $\geq 97.5 \%$ pure) and NADPH (sodium salt; $\geq 97 \%$ pure) were obtained from Roth (Karlsruhe, Germany).

The microorganisms used were E. coli JM109, E. coli BL21 (DE3), S. cerevisiae CEN.PK 113-7D (MATa MAL2-8c SUC2) (termed S. c. wild-type) and S. cerevisiae CEN.PK 113-5D (S. cerevisiae CEN.PK 113-7D - URA; MATa MAL2-8c SUC2 ura3). Pfu DNA polymerase was from Promega (Madison, WI, USA). dNTPs, T4 DNA ligase, and restriction enzymes were from MBI Fermentas (Flamborough, ON, Canada). The ionic liquid 1-butyl-3-methylimidazolium hexafluorophosphate $\left(\mathrm{BMIMPF}_{6}\right)$ was from Sigma-Aldrich (product number 18122). All other chemicals were purchased from Sigma-Aldrich/Fluka (Gillingham, Dorset, U.K.) or Roth (Karlsruhe, Germany), and were of the highest purity available.

\section{Strain construction}

All DNA manipulations and bacterial transformations were carried out according to standard protocols. Cloning of the CbFDH gene (from strain C. boidinii ATCC 18810) into the plasmid vector pBTac1 (pBTac1-FDH) was described previously [49]. The strain E. coli JM109 harbouring pBTac1-FDH was termed E. coli FDH. The pETDuet-1 vector from Novagen (VWR International GmbH, Vienna Austria) was used for co-expression of the genes encoding $C t \mathrm{XR}$ and $\mathrm{CbFDH}$. This vector contains two multiple cloning sites, each of which is preceded by a T7 promoter/lac operator and an optimal ribosome binding site for high level protein expression [50]. The vector also carries a ColE1 replicon, the lacI gene and an ampicillin resistance gene. The gene encoding CtXR (from C. tenuis CBS 4435) was amplified from the plasmid pBEAct.1i 
[51] by a PCR using Pfu DNA polymerase and the following pair of oligonucleotide primers which provided PagI (compatible ends to NcoI) and HindIII restriction sites.

forward primer: 5'- GGTGGTTCATGAGCGCAAGTATCC3',

reverse primer: 5'- ACCACCAAGCTTTTAAACGAAGATTGGAATG -3'.

These restriction sites were used subsequently to clone the gene into the first multiple cloning site of pETDuet-1 (NcoI, HindIII), yielding pETDuet-1-XR. The CbFDH gene was likewise amplified from pBTac1-FDH using the oligonucleotide primers listed below.

forward primer: 5'- GGAATTCCATATGAAGATCGTTTTAG $-3 '$

reverse primer: 5'- ACCACCCCTAGGTTATTTCTTATCGTGTTTAC -3'.

The primers provided $\underline{\mathrm{NdeI}}$ and $\underline{\mathrm{AvrII}}$ restriction sites which were used subsequently to clone the $\mathrm{CbFDH}$ gene into the second multiple coning site of pETDuet-1-XR, yielding pETDuet-1-XR_FDH. E. coli Bl21 (DE3) was transformed with pETDuet-1-XR_FDH using a standard electroporation method. The correct integration of the genes for $C t \mathrm{XR}$ and $\mathrm{CbFDH}$ and the absence of misincorporations of nucleotides due to DNA polymerase errors were verified by sequencing. The resulting strain was termed E. coli XR_FDH. Construction of the strain S. cerevisiae XR2 $\mu$ was described previously [31]. The strain was derived from S. cerevisiae CEN.PK 113-5D and harbours the yeast $2 \mu$ expression plasmid p426GPD that contains the gene for CtXR under control of the strong constitutive glyceraldehyde-3-phosphate dehydrogenase (GPD) promoter.

\section{Cultivation of strains}

E. coli strains were grown in $1000 \mathrm{~mL}$ baffled shaken flasks containing $200 \mathrm{~mL}$ of LB media supplemented with 115 $\mathrm{mg} / \mathrm{L}$ ampicillin. A Certomat ${ }^{\circledR}$ BS-1 incubator from Sartorius was used at a constant agitation rate of $120 \mathrm{rpm}$. Recombinant protein production used a standard procedure in which cultures were cooled from $37^{\circ} \mathrm{C}$ to $25^{\circ} \mathrm{C}$ when an optical density of $1.1( \pm 10 \%)$ was reached. Isopropylthio- $\beta$-D-galactoside (IPTG) was added in a concentration of 0.25 or $1.0 \mathrm{mM}$, and the cultivation time after induction was 5 or $20 \mathrm{~h}$. Cells were harvested by centrifugation and broken up with the lysis reagent B-Per (Pierce, Rockford, IL, USA). S. cerevisiae XR2 $\mu$ was grown and processed as described recently [31].

\section{Enzyme activity measurements in the cell-free extracts}

Reductase and dehydrogenase activities were assayed spectrophotometrically at $25^{\circ} \mathrm{C}$, monitoring the reduction or oxidation of $\mathrm{NAD}(\mathrm{P})(\mathrm{H})$ at $340 \mathrm{~nm}$ over a time of 1-5 min. Typically, rates of $0.05-0.10 \Delta A / \mathrm{min}$ were measured. One unit of enzyme activity refers to $1 \mu \mathrm{mol}$ of $\mathrm{NAD}(\mathrm{P})(\mathrm{H})$ consumed per minute. All measurements were performed with a Beckman DU-800 spectrophotometer using $50 \mathrm{mM}$ potassium phosphate buffer, $\mathrm{pH}$ 7.5. The standard assay for CtXR contained $10 \mathrm{mM}$ ethyl 4cyanobenzoylformate and $250 \mu \mathrm{M}$ NAD(P)H; that for $\mathrm{CbFDH}$ contained $200 \mathrm{mM}$ sodium formate and $2 \mathrm{mM}$ $\mathrm{NAD}^{+}$. Five $\%(\mathrm{v} / \mathrm{v})$ ethanol was added to the buffer to enhance the solubility of ethyl 4-cyanobenzoylformate. Reactions were always started by the addition of coenzyme. Measured rates were corrected for appropriate blank readings accounting for non-specific oxidation or reduction of $\mathrm{NAD}(\mathrm{P})(\mathrm{H})$ by the cell extracts. Protein concentrations were determined with the BCA assay (Pierce) using bovine serum albumin as a standard. Determination of the activities of $\mathrm{CtXR}, \mathrm{ADH}$, and AlDH in the cellfree extract of $S$. cerevisiae was described previously [31].

\section{Enzyme stability measurements}

Reaction mixtures ( $1 \mathrm{~mL}$ total volume) containing 40 $\mathrm{g}_{\mathrm{CDW}} / \mathrm{L}$ E. coli XR_FDH and $100 \mathrm{mM}$ ethyl 4-cyanobenzoylformate in $100 \mathrm{mM}$ potassium phosphate buffer, $\mathrm{pH}$ 7.5 , were incubated in $1.5 \mathrm{~mL}$ Eppendorf tubes at $30^{\circ} \mathrm{C}$. Tubes were incubated for $0.5,1,2,3$ or $4 \mathrm{~h}$. The reaction mixture was diluted 20-fold with buffer such that no organic phase (from insoluble substrate) remained, and cells were then collected by centrifugation. After cell lysis using B-Per, enzyme activities were assayed as described above.

\section{Whole-cell bioreduction of ethyl 4-cyanobenzoylformate}

Experiments were carried out at $30( \pm 1){ }^{\circ} \mathrm{C}$ using $2-\mathrm{mL}$ Eppendorf reaction tubes that were incubated in an endover-end rotator (SB3 from Stuart) at $30 \mathrm{rpm}$. Cells in a concentration between 5 and $80 \mathrm{~g}_{\mathrm{CDW}} / \mathrm{L}$ were suspended in $100 \mathrm{mM}$ potassium phosphate buffer, pH 7.5. Ethyl 4cyanobenzoylformate is a liquid and was added in a concentration between 10 and $500 \mathrm{mM}$ as indicated. Because the solubility of ethyl 4-cyanobenzoylformate was only $10 \mathrm{mM}$ under the conditions used, reactions with substrate concentrations of $>10 \mathrm{mM}$, took place in an aqueous-organic two-phase system. The concentration of sodium formate always exceeded that of the ketone substrate by $50 \mathrm{mM}$ (minimum $150 \mathrm{mM}$ ). The total reaction volume was $1 \mathrm{~mL}$, and conversions were started through addition of substrate. In reactions where a water-immiscible organic co-solvent (ethyl acetate, butyl acetate, hexane) or ionic liquid $\left(\mathrm{BMIMPF}_{6}\right)$ was used, the substrate was dissolved in the co-solvent first and added to the aqueous phase containing the cells in a $1: 1 \mathrm{v} / \mathrm{v}$ ratio. A 
potassium phosphate buffer solution was used as control under otherwise identical conditions. $1 \mathrm{~mL}$ samples were taken at certain times, typically every hour, and analyzed as described under Analytical methods.

Procedures used in whole-cell reductions catalyzed by $S$. cerevisiae XR2 $\mu$ were described in a recent paper [31].

\section{Analytical methods}

Samples were diluted with ethanol as required to obtain a homogeneous liquid phase. Cells were then separated by centrifugation. The supernatant was analyzed by chiral HPLC using a LaChrom HPLC system (Merck-Hitachi) equipped with a reversed phase CHIRALPAK AD-RH column from Daicel (purchased at VWR International, Vienna, Austria) and an L-7400 UV-detector. Detection was at $210 \mathrm{~nm}$. Baseline separation of the $R$ and $S$ antipode in a racemic mixture of ethyl 4-cyanomandelate was obtained when using acetonitrile and water (20:80, by volume) as eluent at a flow rate of $0.5 \mathrm{~mL} / \mathrm{min}$ and a temperature of $40^{\circ} \mathrm{C}$. Authentic (relevant) standards were used for peak identification, and quantification was based on peak area that was suitably calibrated with standards of known concentration. Reported yields of product on substrate consumed are always from analytical data because product isolation (and determination of the overall yield) was beyond the scope of this study.

\section{Competing interests}

The authors declare that they have no competing interests.

\section{Authors' contributions}

RK has made substantial contributions to conception, design of experiments and acquisition of data. Carried out analysis, interpreted the data and has been involved in drafting the manuscript. MP contributed to acquisition of data. SE carried out the molecular genetic work. BN has made substantial contributions to conception, design of experiments, interpretation of data and has drafted the manuscript. All authors read and approved the final manuscript.

\section{Acknowledgements}

The financial support from the Austrian Science Fund (FWF; project DK Molecular Enzymology W90I-B05 and Hertha-Firnberg grant T350-B09) is gratefully acknowledged.

\section{References}

I. Moore JC, Pollard DJ, Kosjek B, Devine PN: Advances in the enzymatic reduction of ketones. Acc Chem Res 2007, 40:1412-1419.

2. Goldberg K, Schroer K, Lütz S, Liese A: Biocatalytic ketone reduction-a powerful tool for the production of chiral alcohols-part II: Whole cell reductions. Appl Microbiol Biotechnol 2007, 76:249-255.

3. Goldberg K, Schroer K, Lütz S, Liese A: Biocatalytic ketone reduction-a powerful tool for the production of chiral alcohols-part I: Processes with isolated enzymes. Appl Microbiol Biotechnol 2007, 76:237-248.
4. Faber K: Reduction Reactions. In Biotransformations in Organic Chemistry 4th edition. Edited by: Faber K. Berlin: Springer; 2000:177-219.

5. Bommarius AS, Riebel BR: Production of enantiomerically pure hydrophobic alcohols: Comparison of different routes and reactor configurations. In Biocatalysis Ist edition. Edited by: Bommarius AS, Riebel BR. Weinheim: Wiley-VCH; 2004:456-569.

6. Ema T, Yagasaki H, Okita N, Takeda M, Sakai T: Asymmetric reduction of ketones using recombinant $E$. coli cells that produce a versatile carbonyl reductase with high enantioselectivity and broad substrate specificity. Tetrahedron 2006, 62:6|43-6149.

7. Ernst M, Kaup B, Müller M, Bringer-Meyer S, Sahm H: Enantioselective reduction of carbonyl compounds by whole cell biotransformation, combining a formate dehydrogenase and a (R)-specific alcohol dehydrogenase. Appl Microbiol Biotechnol 2005, 66:629-634.

8. Kataoka M, Rohani LPS, Yamamoto K, Wada M, Kawabata H, Kita K, Yanase H, Shimizu S: Enzymatic production of ethyl (R)-4chloro-3-hydroxybutanoate: Asymmetric reduction of ethyl 4-chloro-3-oxobutanoate by an Escherichia coli transformant expressing the aldehyde reductase gene from yeast. Appl Microbiol Biotechnol 1997, 48:699-703.

9. Xu Z, Liu Y, Fang L, Jiang X, Jing K, Cen P: Construction of a twostrain system for asymmetric reduction of ethyl 4-chloro-3oxobutanoate to (S)-4-chloro-3-hydroxybutanoate ethyl ester. Appl Microbiol Biotechnol 2006, 70:40-46.

10. Zhang J, Witholt B, Li Z: Coupling of permeabilized microorgansims for efficient enantioselective reduction of ketone with cofactor recycling. Chem Commun 2006, 4:398-400.

II. Gröger H, Chamouleau F, Orologas N, Rollmann C, Drauz K, Hummel W, Weckbecker A, May O: Enantioselective reduction of ketons with 'designer cells' at high substrate concentrations: Highly efficient access to functionalized optically active alcohols. Angew Chem Int Ed 2006, 45:5677-568I.

12. Ema T, Okita N, Ide S, Sakai T: Highly enantioselective and efficient synthesis of methyl (R)-o-chloromandelate with recombinant $E$. coli : Toward practical and green access to clopidogrel. Org Biomol Chem 2007, 5: I I75- I I76.

13. Kataoka M, Kita K, Wada M, Yasohara Y, Hasegawa J, Shimizu S: Novel bioreduction system for the production of chiral alcohols. Appl Microbiol Biotechnol 2003, 62:437-445.

14. Yun H, Choi H-L, Fadnavis NW, Kim B-G: Stereospecific synthesis of $(R)-2-h y d r o x y$ carboxylic acids using recombinant $E$. coli BL2I overexpressing YiaE from Escherichia coli KI 2 and glucose dehydrogenase from Bacillus subtilis. Biotechnol Prog 2005, 21:366-37l.

15. De Anda R, Lara AR, Hernández V, Hernández-Montalvo V, Gosset G, Bolívar F, Ramírez OT: Replacement of the glucose phosphotransferase transport system by galactose permease reduces acetate accumulation and improves process performance of Escherichia coli for recombinant protein production without impairment of growth rate. Metab Eng 2006, 8:281-290.

16. Wong MS, Wu S, Causey TB, Bennett GN, San K-Y: Reduction of acetate accumulation in Escherichia coli cultures for increased recombinant protein production. Metab Eng 2008, 10:97-108.

17. Kaup B, Bringer-Meyer S, Sahm H: Metabolic engineering of Escherichia coli : Construction of an efficient biocatalyst for D-mannitol formation in a whole-cell biotransformation. Appl Microbiol Biotechnol 2004, 64:333-339.

18. Nordkvist M, Nielsen PM, Villadsen J: Oxidation of lactose to lactobionic acid by a Microdochium nivale carbohydrate oxidase: Kinetics and operational stability. Biotechnol Bioeng 2007, 97:694-707.

19. Nidetzky B, Neuhauser W, Haltrich D, Kulbe KD: Continuous enzymatic production of xylitol with simultaneous coenzyme regeneration in a charged membrane reactor. Biotechnol Bioeng 1996, 52:387-396.

20. Nidetzky B, Fürlinger M, Gollhofer D, Scopes RK, Haltrich D, Kulbe KD: Improved operational stability of cell-free glucose-fructose oxidoreductase from Zymomonas mobilis for the efficient synthesis of sorbitol and gluconic acid in a continuous ultrafiltration membrane reactor. Biotechnol Bioeng 1997, 53:623-629. 
21. Nidetzky B, Mayr P, Hadwiger P, Stütz AE: Binding energy and specificity in the catalytic mechanism of yeast aldose reductase. Biochem J 1999, 344:101-107.

22. Bräutigam S, Bringer-Meyer S, Weuster-Botz D: Asymmetric whole cell biotransformations in biphasic ionic liquid/watersystems by use of recombinant Escherichia coli with intracellular cofactor regeneration. Tetrahedron: Asymm 2007, 18:1883-1887.

23. Weckbecker A, Hummel W: Improved synthesis of chiral alcohols with Escherichia coli cells co-expressing pyridine nucleotide transhydrogenase, NADP+-dependent alcohol dehydrogenase and NAD+-dependent formate dehydrogenase. Biotechnol Lett 2004, 26:1739-1744.

24. Yamamoto H, Mitsuhashi K, Kimoto N, Kobayashi Y, Esaki N: Robust NADH-regenerator: Improved $\alpha$-haloketone-resistant formate dehydrogenase. Appl Microbiol Biotechnol 2005, 67:33-39.

25. Menzel A, Werner H, Altenbuchner J, Gröger H: From enzymes to 'designer bugs' in reductive amination: $A$ new process for the synthesis of L- tert-leucine using a whole cell-catalyst. Eng Life Sci 2004, 4:573-576.

26. Gröger H, Hummel W, Rollmann C, Chamouleau F, Hüsken H, Werner H, Wunderlich C, Abokitse K, Drauz K, Buchholz S: Preparative asymmetric reduction of ketones in a biphasic medium with (S)-alcohol dehydrogenase under in situ-cofactor-recycling with formate dehydrogenase. Tetrahedron 2004, 60:633-640.

27. Mesentsev AV, Lamzin VS, Tishkov VI, Ustinnikova TB, Popov VO: Effect of pH on kinetic parameters of NAD+-dependent formate dehydrogenase. Biochem J 1997, 32 1:475-480.

28. Slusarczyk H, Felber S, Kula MR, Pohl M: Stabilization of NADdependent formate dehydrogenase from Candida boidinii by site-directed mutagenesis of cysteine residues. Eur J Biochem 2000, 267:1280-1289.

29. Kratzer R, Nidetzky B: Identification of Candida tenuis xylose reductase as highly selective biocatalyst for the synthesis of chiral $\alpha$-hydroxy esters and improvement of its efficiency by protein engineering. Chem Comm 2007, 10:1047-1049.

30. Meaden PG, Dickinson FM, Mifsud A, Tessier W, Westwater J, Bussey H, Midgley M: The ALD6 gene of Saccharomyces cerevisiae encodes a cytosolic, $\mathbf{M g}^{2+}$-activated acetaldehyde dehydrogenase. Yeast 1997, 13:1319-1327.

3I. Kratzer R, Egger S, Nidetzky B: Integration of enzyme, strain and reaction engineering to overcome limitations of baker's yeast in the asymmetric reduction of $\alpha$-keto esters. Biotechnol Bioeng 2008, I01:1094-II0I.

32. Kaluzna IA, Matsuda T, Sewell AK, Stewart JD: Systematic investigation of Saccharomyces cerevisiae enzymes catalyzing carbonyl reductions. J Am Chem Soc 2004, 1 26: I 2827- 12832.

33. Modig T, Almeida JRM, Gorwa-Grauslund MF, Lidén G: Variability of the response of Saccharomyces cerevisiae strains to lignocellulose hydrolysate. Biotechnol Bioeng 2008, 100:423-429.

34. Pfruender H, Ross J, Weuster-Botz D: Water immiscible ionic liquids as solvents for whole cell biocatalysis. J Biotechnol 2006, 124:182-190.

35. Kim P-Y, Pollard DJ, Woodley JM: Substrate supply for effective biocatalysis. Biotechnol Prog 2007, 23:74-82.

36. Li Y-N, Shi X-A, Zong M-H, Meng C, Dong Y-Q, Guo Y-H: Asymmetric reduction of 2-octanone in water/organic solvent biphasic system with baker's yeast FD- 12. Enzyme Microb Technol 2007, 40:1305-1311.

37. Sybesma WFH, Straathof AJJ, Jongejan JA, Pronk JT, Heijnen JJ: Reductions of 3-oxo esters by baker's yeast: Current status. Biocatal Biotransform 1998, 16:95-134.

38. Johanson T, Katz M, Gorwa-Grauslund MF: Strain engineering for stereoselective bioreduction of dicarbonyl compounds by yeast reductases. FEMS Yeast Res 2005, 5:5 I 3-525.

39. Andersson M, Holmberg H, Adlercreutz P: Evaluation of Alcaligenes eutrophus cells as an NADH regenerating catalyst in organic-aqueous two-phase system. Biotechnol Bioeng 1998, 57:79-86.

40. Andersson M, Otto R, Holmberg H, Adlercreutz P: Alcaligenes eutrophus cells containing hydrogenase, a coenzyme regenerating catalyst for NADH-dependent oxidoreductases. Biocatal Biotransform 1997, 1 5:281-296.
41. Adlercreutz P: Novel biocatalyst for the asymmetric reduction of ketones: Permeabilized cells of Gluconobacter oxydans. Enzyme Microb Technol 1991, 13:9-14.

42. Felix $\mathrm{H}$, Brodelius $\mathrm{P}$, Mosbach $\mathrm{K}$ : Enzyme activities of the primary and secondary metabolism of simultaneously permeabilized and immobilized plant cells. Anal Biochem 1981, I 1 6:462-470.

43. Honorat-Pascal A, Monot F, Ballerini D: Comparative study of the enzymatic synthesis of $L$-valine by purified enzymes, crude extract, intact or permeabilized cells from Bacillus megaterium. Appl Microbiol Biotechnol 1990, 34:236-24I.

44. Cánovas M, Torroglosa T, lborra JL: Permeabilization of Escherichia coli cells in the biotransformation of trimethylammonium compounds into L-carnitine. Enzyme Microb Technol 2005, 37:300-308.

45. Tsubery H, Ofek I, Cohen S, Fridkin M: Structure-function studies of polymyxin B nonapeptide: Implications to sensitization of gram-negative bacteria. J Med Chem 2000, 43:3085-3092.

46. Walton AZ, Stewart JD: Understanding and improving NADPH-dependent reactions by non-growing Escherichia coli cells. Biotechnol Progr 2004, 20:403-4II.

47. Kratzer R, Kavanagh KL, Wilson DK, Nidetzky B: Study of the enzymic mechanism of Candida tenuis xylose reductase (AKR2B5): X-ray structure and catalytic reaction profile for the HI I 3A mutant. Biochemistry 2004, 43:4944-4954.

48. Tishkov VI, Popov VO: Protein engineering of formate dehydrogenase. Biomol Eng 2006, 23:89-IIO.

49. Krahulec S, Armao GC, Weber H, Klimacek M, Nidetzky B: Characterization of recombinant Aspergillus fumigatus mannitol-Iphosphate 5-dehydrogenase and its application for the stereoselective synthesis of protio and deuterio forms of D-mannitol I-phosphate. Carbohydr Res 2008, 343:|4|4-I423.

50. Novy R, Yaeger K, Held D, Mierendorf R: Coexpression of multiple target proteins in E. coli. inNovations 2002, I5:2-6.

51. Häcker B, Habenicht A, Kiess M, Mattes R: Xylose utilisation: Cloning and characterisation of the xylose reductase from Candida tenuis. Biol Chem 1999, 380:1395-1403.
Publish with Bio Med Central and every scientist can read your work free of charge

"BioMed Central will be the most significant development for disseminating the results of biomedical research in our lifetime."

Sir Paul Nurse, Cancer Research UK

Your research papers will be:

- available free of charge to the entire biomedical community

- peer reviewed and published immediately upon acceptance

- cited in PubMed and archived on PubMed Central

- yours - you keep the copyright

Submit your manuscript here:

http://www.biomedcentral.com/info/publishing_adv.asp
BioMedcentral 